\title{
Noty o Autorach
}

Nataša AVRAMOVSKA - literaturoznawca, profesor w Instytucie Literatury Macedońskiej w Skopju oraz na podyplomowych i doktoranckich studiach kulturologicznych na Uniwersytecie śś. Cyryla i Metodego. W polu jej komparatystycznych zainteresowań badawczych leży narratologia, dramaturgia, teatrologia i studia gender. Autorka licznych prac z tego zakresu, m.in. książek: Травестија на усната историја - раскажувачкиот криптограм на Петре М. Андреевски (1999), Ex Libris (2000), Во вителот на дереализаиијата (дуплото дно на македонската драма) (2004), Автобиограбијата во македонскиот литературен 19 век (2004), Ние во времето (2006), Во светот на зборовите (2011), współredaktorka tomu Interpretations, vol. 4/5 New Literary Theory and Hermeneutics (2011, z K. Kulavkovą). Tłumaczy z języka niemieckiego i chorwackiego teksty naukowe i literaturę piękną. Od 2004 r. jest redaktorem pisma „Културен живот”, a od 2011 r. także wydawanego w formie elektronicznej e-pisma „Блесок”.

Kontakt: natasha.avramovska@yahoo.com

\section{$\mathscr{8 0}$}

Iskra BAEWA - historyk, profesor na Wydziale Historycznym Uniwersytetu Sofijskiego im. św. Klimenta Ochrydzkiego. Zajmuje się historią Europy Wschodniej i świata po II wojnie światowej, szczególną uwagę poświęcając okresowi zimnej wojny. Autorka licznych monografii dotyczących współczesnej Europy Środkowo-Wschodniej: Източна Европа след Сталин 1953-1956. Полша, Унгария, Чехословакия и България (1995), България и Източна Европа (2001), Тодор Живков (2006), Източна Европа през ХХ в. - идеи, конфликти, митове (2010). We współpracy z Eugenią Kalinową opublikowała prace: La Bulgarie contempotaine entre l'Est et l'Ouest (Paris 2001), Птрвото следвоенно десетилетие на българската вънина политика 1944-1955 (2003), Българските преходи 1939-2010 (2010), Bulgarien von Ost nach West. Zeitgeschichte ab 1939 (Wien 2009), Социализмбт в огледалото на прехода (2011).

Kontakt: iskravbaeva@yahoo.com 
Beata CIESZYŃSKA - literaturoznawca, doktor nauk humanistycznych, pracuje na Uniwersytecie w Lizbonie, gdzie pełni też funkcję wicedyrektora i koordynatora grupy badawczej „Interkulturowość Iberyjsko-Słowiańska” w centrum naukowym Centro de Literaturas e Culturas Lusófonas e Europeias da Faculdade de Letras da Universidade de Lisboa (CLEPUL). Przewodnicząca Komisji Iberyjsko-Słowiańskich Badań Komparatystycznych przy Międzynarodowym Komitecie Slawistów oraz Komisji Naukowej Międzynarodowego Stowarzyszenia do Studiów Iberyjsko-Słowiańskich - CompaRes. Jej zainteresowania badawcze oscylują wokół sensualizmu w literaturze i kulturze baroku, mitów i stereotypów w odczytaniu „obcego” z perspektywy polsko-brytyjskiej i iberyjsko-słowiańskiej. Autorka licznych artykułów naukowych i monografii Okna duszy. Pięć zmysłów w literaturze barokowej (Bydgoszcz 2006), także redaktorka tomów: Iberian and Slavonic Cultures: Contact and Comparison (Lisbon 2007), roczników „IberoSlavica” (2010, 2011), półrocznika „Letras Com Vida” (nr 1-4). Wspólnie z José Eduardo Franco i Teresą Pinheiro jest współwydawcą tomów zbiorowych: Peripheral Identities. Iberia and Eastern Europe between the Dictatorial Past and the European Present (Glasgow-Lisbon-Warsaw-Chemnitz 2011), Ideas of/for Europe. An Interdisciplinary Approach to the European Identity (Berlin-Oxford 2012).

Kontakt: compares.compares@gmail.com

\section{$\mathscr{0}$}

Maciej CZERWIŃSKI - filolog i tłumacz, adiunkt w Instytucie Filologii Słowiańskiej Uniwersytetu Jagiellońskiego. Zajmuje się - zarówno teoretycznie, jak i empirycznie - semiotyką (semiotyką kultury), stylistyką, socjolingwistyczną analizą dyskursu oraz pograniczami teorii języka i literatury. Współredaktor prac z zakresu semiotyki kultury i języka, m.in.: Josip Juraj Strossmayer, Chorwacja, ekumenizm, Europa (2007), Język IV Rzeczypospolitej (2010), Kraków - Zagrzebiowi / Krakov - Zagrebu (Zagreb 2011, reprint albumu z 1881), autor licznych artykułów i książek poświęconych tej problematyce, m.in.: Język, ideologia, naród. Polityka językowa w Chorwacji a język mediów (2005), Semioza gatunku - semioza stylu. Studium nad chorwacka i serbska synteza dziejów narodu (2011), Semiotyka dyskursu historycznego. Kody i znaki w chorwackiej i serbskiej syntezie dziejów narodu (2012).

Kontakt: maciej.czerwinski@uj.edu.pl 
Simona GRUEVSKA-MADŽOSKA - językoznawca, profesor w Instytucie Języka Macedońskiego im. Krste Misirkova w Skopju. Zakres jej zainteresowań badawczych obejmuje socjolingwistykę, leksykologię, stylistykę i semantykę. Kierownik narodowego projektu badawczego „Речник на синоними во македонскиот јазик”. Autorka licznych artykułów naukowych publikowanych w Macedonii i poza jej granicami, m.in.: Лексички и стилски особености на творештвото на Живко Чинго (2008), Комуникацијата на младите преку Интернет и СМС-пораки (2009), Состојбата во македонскиот и во хрватскиот јазик од соииолингвистички аспект (Rijeka 2011), Language, Borders, Identity (Bacau 2012), a także monografii: Лексuчката синонимија во македонскиот стандарден јазик (2009), Социолингвистички огледи (2010).

Kontakt: simonagrum@yahoo.com

\section{$\mathscr{1 0}$}

Anna KOBYLIŃSKA - doktor nauk humanistycznych w zakresie kulturoznawstwa, adiunkt w Instytucie Slawistyki Zachodniej i Południowej Uniwersytetu Warszawskiego. Jej zainteresowania naukowe to ezoteryczne nurty kultury, historia idei i ikonologia, relacje międzykulturowe, słowiańskie narracje peryferyjne. Autorka wielu artykułów naukowych, m.in.: Gnoza w cyklu Dráma sveta Janka Krála, [w:] Wielkie tematy kultury w literaturach słowiańskich 7, cz. 2, red. M. Bukwalt, T. Klimowicz et al. (2007), W trwodze poszukiwań utraconej tożsamości, czyli kim jest autor? (Hladanie strateného autora według Dušana Mitany), [w:] Slavica leguntur. Aktualne problemy badawcze slawistyki, red. J. Królak, J. Molas (2006), Konflikt idei w eposie religijnym Jonáša Záborskiego Vstúpenie Krista do Rája, [w:] Biblia Slavorum Apocryphorum. Novum Testamentum, red. G. Minczew, M. Skowronek, I. Petrov (2009), współredaktor tomu zbiorowego Czarny romantyzm - przypadek słowacki (2011, z J. Goszczyńską) i autorka monografii Tropem Hermesa. Przypadek słowackiego księdza, myśliciela i literata Jonáša Záborskiego (2012).

Kontakt: a.kobylinska@uw.edu.pl

\section{$\mathscr{P a}$}

Sanjin KODRIĆ - historyk literatury, docent na Wydziale Filozoficznym Uniwersytetu w Sarajewie. Zajmuje się nowszą literaturą boszniacką i bośniacko-hercegowińską, współczesnymi teoriami kultury i pamięci kulturowej, komparatystyką literacką i związkami literackimi w kontekście literatur 
południowosłowiańskich. Jest kierownikiem Komisji Literatury i Studiów Kulturowych Komitetu Slawistów BiH, redaktorem serii „Bosnistika”, członkiem prezydium Bośniackiego Towarzystwa Filologicznego, gdzie pełni funkcję redaktora czasopisma literackiego „Pismo”, członkiem Komisji Komparatystycznej przy Międzynarodowym Komitecie Slawistów oraz kolegiów redakcyjnych pism: „Philological Studies”, „Południowosłowiańskie Zeszyty Naukowe” i „Poznańskie Studia Slawistyczne”. Autor ponad 60 artykułów poświęconych literaturze boszniackiej i bośniacko-hercegowińskiej XIX i XX w., a także dwóch monografii: Književna prošlost i poetika kulture: Teorija novog historicizma u bosanskohercegovačkoj književnohistorijskoj praksi (2010) i Književnost sjećanja: Kulturalno pamćenje i reprezentacija prošlosti u novijoj bošnjačkoj književnosti (2012).

Kontakt: sanjin.kodric@ff.unsa.ba; sanjin_o_kodric@hotmail.com

\section{$\mathscr{8 0}$}

Mirella KORZENIEWSKA-WISZNIEWSKA - politolog, adiunkt w Instytucie Nauk Politycznych i Stosunków Międzynarodowych Uniwersytetu Jagiellońskiego. Obszar jej zainteresowań naukowych obejmuje Bałkany, szczególnie państwa byłej Jugosławii, i dzieje tego regionu po 1991 r. oraz sytuację mniejszości narodowych i etnicznych. Jest członkiem Komisji Bałkanistyki Polskiej Akademii Nauk, Komisji Środkowoeuropejskiej Polskiej Akademii Umiejętności oraz Polskiej Komisji ds. Kultury i Historii Bałkanów afiliowanej przy Association of South-East European Studies (AIESEE). Najważniejsze publikacje: Geneza konfliktu serbsko-albańskiego w Kosowie w latach 19681998 na tle wewnętrznej polityki jugosłowiańskiej - próba analizy, „Studia z Dziejów Rosji i Europy Środkowo-Wschodniej" (t. 43, 2008), Serbia and the European Union at the beginning of the twenty first century (In the light of the Serbia media), „Politeja” (nr 10/1, 2009), Zjawisko jugonostalgii w pierwszej dekadzie XXI w., „Rocznik Instytutu Europy Środkowo-Wschodniej. Region Bałkański” (t. 7/2, 2009), Stanowisko Serbskiej Cerkwi Prawosławnej wobec zmian w polityce serbskiej po 2000 roku, „Balcanica Posnaniensia. Acta et studia" (t. 17, 2010), Republika Serbii i Republika Serbska a Serbowie - sytuacja obecna i perspektywy, [w:] Bośnia i Hercegowina 15 lat po Dayton-przeszłość, teraźniejszość i przyszłość, red. P. Chmielewski, S. L. Szczesio (2011), Serbska diaspora wXX wieku. Rzeczywistość a schematy i uogólnienia, [w:] Stereotypy bałkańskie, red. J. Paszkiewicz, Z. Pentek (2011).

Kontakt: mirellakorzeniewska@poczta.onet.pl 


\section{$\mathscr{B a}$}

Katica KULAVKOVA (Kata ĆULAVKOVA) - literaturoznawca, profesor teorii literatury, kreatywnego pisania i hermeneutyki literackiej na Uniwersytecie śś. Cyryla i Metodego w Skopju, pisarka i eseistka. Jest członkiem wielu instytucji naukowych i literackich, m.in.: członkiem rzeczywistym Macedońskiej Akademii Nauk i Sztuk, Stowarzyszenia Komparatystów Macedonii, Związku Pisarzy Macedońskich, pełni też funkcję wiceprezesa Międzynarodowego PEN Clubu, jest wydawcą International PEN Collection Diversity (www.diversity. org.mk). Uczestniczy w licznych międzynarodowych projektach naukowo-badawczych. Jest redaktorem tomów zbiorowych i antologii tekstów, np.: New, Poetics and Hermeneutics (2003), Dialogue of Interpretations (2005), Theory of Intertextuality (2003), Balkan Image of the World (2006), Glossary of Literary Theory (2007), Interpretations: vol. 1 Violence and Art (2007), vol. 2 Memory and Art (2008), vol. 3 The Black Arab as a Figure of Memory (2009). Autorka ważnych prac z zakresu teorii literatury i hermeneutyki literackiej, m.in.: Figurative Speech and Macedonian Poetry (1984), Pact and Impact (1987), Stone of Temptation (1997), Small Literary Theory (2001), Theory of Literature (2004), Hermeneutics of Identities (2009), The Demon of Interpretation (2009), Macedonian Temptations and other essays (2012).

Pełna bibliografia: www.kulavkova.org.mk

Kontakt: poetiki@sonet.com.mk

\section{$\mathscr{8 0}$}

Lilla MOROZ-GRZELAK - literaturoznawca, adiunkt w Zakładzie Literaturoznawstwa i Kulturoznawstwa Instytutu Slawistyki Polskiej Akademii Nauk. Jej zainteresowania badawcze koncentrują się wokół literatury, kultury i historii Słowian południowych (szczególnie Serbii i Macedonii) oraz mitów ideologicznych Słowiańszczyzny południowej. Jest m.in. członkiem Komisji Ibero-Slawistycznej przy Międzynarodowym Komitecie Slawistów, Międzynarodowego Komitetu Redakcyjnego pisma „Istorija” w Macedonii. Autorka tekstów naukowych publikowanych w czasopismach w kraju i za granicą („Pamiętnik Słowiański”, „Studia z Filologii Polskiej i Słowiańskiej”, „Slavia Meridionalis”, „,ОФIA. Pismo Filozofów Krajów Słowiańskich”, „Z Polskich Studiów Slawistycznych”, „Studia z Dziejów Rosji i Europy Środkowo-Wschodniej”, „Sprawy Narodowościowe”, „Przegląd Humanistyczny”, „Tokovi istorije”, „Spektar”, „Folia Philologica Macedono-Polonica”), a także współautorka kompendium bibliograficznego o indywidualnych dokonaniach slawistów 
ostatnich pięciu lat XX w. Bibliografia słowianoznawstwa polskiego za lata 1996-2000. Słowiańszczyzna zachodnia i południowa (2002, z P. Głogowskim i M. Stefańskim). Jej dorobek naukowy obejmuje również książki: Aleksander Wielki a macedońska idea narodowa. Słowiańskie losy postaci antycznej (2004) i Bracia Słowianie. Wizje wspólnoty a rzeczywistość (2011).

Kontakt: lilamor@poczta.onet.pl

\section{$\mathscr{8 0}$}

Liljana PANDEVA - absolwentka Wydziału Filologicznego Uniwersytetu śś. Cyryla i Metodego w Skopju, przygotowuje tam doktorat na temat adwerbalizacji w języku macedońskim. Jest również pisarką. Jej zainteresowania naukowe kierują się ku współczesnemu językowi macedońskiemu i językowi poezji macedońskiej. Jest autorką licznych artykułów naukowych, m.in.: Одомаќени зборови (1990), Нови зборови во воената терминологија (1997), Воената терминологија и военоадминистративната лексика во учебникот „Одбрана за средно образование”, „Литературен збор” (2000), Употребата на големата буква во македонскиот стандарден јазик, Зборник „Денови на Благоја Корубин" (2010), Поетските фбгури на формата во поезијата на Славко Јаневски, Зборник „Научна дискусија - литература, Меѓународен семинар за македонски јазик, литература и култура 2010" (2011), Поетските фигури на формата во поезијата на Гане Тодоровски, Зборник „Научна дискусија - литература, Меѓународен семинар за македонски јазик, литература и култура 2011" (2012).

Kontakt: lile_pandeva@hotmail.com

ba

Jędrzej PASZKIEWICZ - historyk, adiunkt w Instytucie Historii Uniwersytetu im. Adama Mickiewicza, członek Komisji Bałkanistyki Polskiej Akademii Nauk (Oddział w Poznaniu), Komisji Bałkańskich Studiów Historycznych i Kulturowych afiliowanej przy International Association of South-East European Studies (AIESEE). W polu jego zainteresowań badawczych pozostaje historia społeczno-polityczna państw i narodów na Bałkanach w XIX i XX w. Jest autorem licznych artykułów naukowych, m.in.: The problem of the Greek national security against the political changes in the Balkans after the signing of the peace treaty of Lausanne (1923-1934), „Studia Balcanica” (t. 27, Sofia 2010/2011), Influence of immigrants from Asia Minor on the social and economic modernization in interwar Greece, [w:] Migrationsprozesse und gesellschaftlicher 
Wandel in der Geschichte, red. P. Matusik, P. Kehne (Poznań 2011) i monografii Jugosławia w polityce Włoch w latach 1914-1941 (2004), Grecja a bezpieczeństwo międzynarodowe na Bałkanach 1923-1935 (2012).

Kontakt: paszje@wp.pl

\section{$\mathscr{P a}$}

Davor PISKAČ - doktor nauk humanistycznych w zakresie teorii literatury, członek Macierzy Chorwackiej (Matica Hrvatska); zatrudniony na stanowisku docenta, prowadzi zajęcia z komparatystyki literackiej na Uniwersytecie w Zagrzebiu. Autor artykułów, m.in.: Estetska funkcija u usmenoj književnosti, "Narodna umjetnost” (nr 6, 2007), Verizam u „Pirici” Petra M. Andreevskog, zbornik „Hrvatsko-makedonske književne i kulturne veze” (Rijeka-Skopje 2007), Teorija invokacije, „Spektar” (t. 9, Skopje 2007), Praški književni strukturalizam: povijest i perspektive, „Umjetnost riječi” (nr 6, 2008) oraz poradnika metodologicznego Kako napisati esej na državnoj maturi (2009).

Kontakt:dpiskac@hrstud.hr

\section{\&a}

Nade PROEVA - profesor historii starożytnej na Wydziale Filozoficznym Uniwersytetu śś. Cyryla i Metodego w Skopju, gdzie wykłada historię antycznej Grecji, Rzymu, Macedonii i ludów wschodnich. Od 1982 r. opublikowała ponad 600 artykułów. Najliczniejsze z wydanych prac dotyczą epigrafiki i onomastyki antycznej oraz religii i kultury antycznych Macedończyków ze szczególnym uwzględnieniem ikonografii. Jest autorką pionierskich w Macedonii monografii naukowych, m.in.: Студии за античките Македониц (1997), Историја на Аргеадите (2004). Przełożyła z francuskiego, opatrując wstępem i przypisami, monografie poświęcone antycznej Grecji i Macedonii, wśród nich Pierra Brianta Александар Велики (1997). Jest redaktorem naukowym serii „Miscellanea Byzantino-macedonica” i „Historia Antiqua Macedonica”, uczestniczy w międzynarodowych projektach badawczych prowadzonych m.in. w Instytucie Archeologii w Belgradzie, w Serbskiej Akademii Nauk i Sztuk oraz Berlińskiej Akademii Nauk.

Kontakt: nproeva@gmail.com 
Alicja PSTYGA - profesor językoznawstwa w Katedrze Językoznawstwa Wschodniosłowiańskiego i Translatoryki Instytutu Filologii Wschodniosłowiańskiej Uniwersytetu Gdańskiego. Jej zainteresowania badawcze obejmują problemy innowacji leksykalnych we współczesnych językach słowiańskich, słowotwórstwo współczesnego języka rosyjskiego i polskiego w ujęciu porównawczym oraz szeroko rozumianą komunikację międzykulturową, szczególnie konfrontacje przekładowe w obrębie języków słowiańskich. Jest autorką licznych, publikowanych w kraju i zagranicą, artykułów, m.in.: Problemy teoretyczne współczesnego językoznawstwa a praktyka leksykograficzna ( $z$ perspektywy opracowań neograficznych języków słowiańskich) (2002), Negacja prefiksalna: opis leksykograficzny i interpretacja (Praha 2005), Текстообразующие потенции словообразовательных морфем, [w:] Мир русского слова и русское слово в мире (Sofia 2007), Культура и язык в коммуникативном пространстве масс-медиа (Bergamo-Belgorod 2010), O perspektywach polsko-macedońskiego dialogu międzykulturowego (Skopje 2010), redaktorka naukowa prac poświęconych translatoryce oraz autorka monografii: Nowe słownictwo rosyjskie: struktura formalna i semantyczna rzeczownika (1994), Innowacje leksykalne we współczesnym języku rosyjskim i polskim. Rzeczownik - studium konfrontatywne (1999), Słowotwórcza kategoria negacji: prefiksalne negatywa rzeczownikowe we współczesnym języku polskim i rosyjskim (2010).

Kontakt: alicjapstyga@interia.pl

\section{$\mathscr{8 0}$}

Biljana RISTOVSKA-JOSIFOVSKA - profesor historii na Wydziale Bałkanologii Instytutu Historii Narodowej w Skopju, koordynator programu studiów podyplomowych „Historia kultury Macedonii”, członek kolegium redakcyjnego pisma „Филолошки студии”. W okresie 2007-2008 przewodnicząca Związku Historyków Republiki Macedonii. Autorka monografii: „Кралството на Словените" од Мавро Орбини како извор за македонската средновековна историја (2001), Горѓија М. Пулевски - револуционер и културно-национален деeu (2008). Współautorka słownika poświęconego mitologii narodowej Macedończyków Речник на народната митологија на Македониите (2000, 2001) i encyklopedii Македонска енциклопедија (2009). Uczestniczy w wielu międzynarodowych projektach badawczych, m.in. jako koordynator. Artykuły naukowe publikuje w licznych pismach, m.in.: „Филолошки студии”, „Гласник”, „Историја”, „Ethnologia Balcanica”, „Balcanistic Forum”, „Македонски фолклор”, „Symposia. Journal for Studies in Ethnology and Anthropology”.

Kontakt: brjosifovska@yahoo.com 


\section{$\mathscr{8 0}$}

Jarosław RUBACHA - historyk, bałkanista, adiunkt na Wydziale Humanistycznym Uniwersytetu Warmińsko-Mazurskiego w Olsztynie. Jego zainteresowania badawcze koncentrują się wokół historii politycznej Półwyspu Bałkańskiego na przełomie XIX i XX w. ze szczególnym uwzględnieniem historii I wojny światowej (front wschodni i bałkański), dziejów Bułgarii i słowianofilstwa polskiego. Członek Macedońskiego Instytutu Naukowego w Sofii oraz Komisji Bałkanistyki przy oddziale Polskiej Akademii Nauk w Poznaniu. Autor licznych artykułów, m.in.: Българо-румбнски спор за Добруджа 1912-1913 г. (В тьрсене на националния идеал 1878-1913) (Błagojewgrad 2009), Od abdykacji do restauracji. Obraz bułgarskiego życia politycznego w latach 1886-1908, [w:] Przeszłość i teraźniejszość. Prace ofiarowane prof. Adamowi Koseskiemu $w$ siedemdziesiąta rocznice urodzin (2009), Bułgarzy w walce o niepodległość w XIX w., „Przegląd Wschodnioeuropejski” (2010), autor monografii Bułgarski sen o Bizancjum. Bułgarska polityka zagraniczna w latach 1878-1913 (2004) i współautor trzytomowego studium Historia Bułgarii 1870-1915. Materiały źródłowe z komentarzami (2006, 2007, 2009).

Kontakt: j.rubacha@wp.pl

\section{$\mathscr{8 a}$}

Sylwia SIEDLECKA - adiunkt w Instytucie Slawistyki Polskiej Akademii Nauk, badaczka kultury i literatury bułgarskiej XX w. w kontekście historii idei i kultury popularnej. Najważniejsze publikacje: Strategie autobiograficzne w powieści Rudolfa Slobody „Rozum”, [w:] Slavica leguntur. Aktualne problemy badawcze slawistyk (2006), Eastern Slovakian inspirations in the collections of short stories „Marakéš" and „Bude to pekný pohreb” by Václav Pankovčín, „Biuletyn Stypendystów Funduszu Wyszehradzkiego" (Bratislava 2007), Ironie jako postoj v textech Bohumila Hrabala „Obsluhoval jsem anglického krále” a „Př́liš hlučná samota", [w:] Funkce - funkčnost - funkcionalismus. VI Mezinárodní Setkání Mladých Lingvistů (Olomouc 2007), Echa „procesu odrodzeniowego" w eseistyce Błagi Dimitrowej, [w:] Przemilczenia w relacjach międzykulturowych (2008), Bułgarskie heterotopie, [w:] Znaczace przestrzenie Słowiańszczyzny (2011), Art, politics and intellectuals in totalitarian Bulgaria (Blaga Dimitrova), Symposium on South Eastern Europe, London School of Economics, tekst dostępny on-line: http://www2.lse.ac.uk/europeanInstitute/research/LSEE/ PDF\%20Files/PhD\%20Symposium/Papers\%202010/Siedlecka.pdf.

Kontakt: siedlecka.sylwia@gmail.com 


\section{$\mathscr{0}$}

Andreja SRŠEN - doktor socjologii, badaczka współczesnych teorii socjologicznych, członek Chorwackiego Towarzystwa Politologicznego (Hrvatsko politološko društvo), wykłada na Uniwersytecie w Zagrzebiu. Autorka prac z zakresu tożsamości chorwackiej w kontekście integracji europejskiej, m.in.: Hrvatska u predpristupnim programima Europske unije, „Međunarodne studije” (nr 3, 2005), Konstrukcija europskog identiteta. Pitanje nacionalnog identiteta u procesu europskih integracja (2010).

Kontakt: asrsen@hrstud.hr

\section{$\mathscr{6 0}$}

Zvonko TANESKI - doktor nauk humanistycznych, zatrudniony na pierwszym prywatnym uniwersytecie macedońskim FON University w Skopju, krytyk literacki i eseista, autor tomów poetyckich. Członek wielu stowarzyszeń naukowych, m.in.: Europejskiej Sieci Komparatystycznych Badań Literackich (European Network for Comparative Literary Studies), Komisji Poetyki i Stylistyki przy Międzynarodowym Komitecie Slawistów oraz Słowackiego Towarzystwa Naukowego Bizantynistów, zasiada w radzie naukowej pisma „Interdisciplinary Journal of Psycholinguistics and Sociolinguistics” w Berlinie. Jest współredaktorem słowackich publikacji akademickich: Duchovné, intelektuálne a politické pozadie cyrilo-metodskej misie pred jej príchodom na Velkú Moravu (Nitra 2007), Poznávanie kultúrneho dedičstva sv. Cyrila a Metoda (Nitra 2007), Význam kultúrneho dedičstva sv. Cyrila a Metoda pre Európu (Nitra 2008) i Európske kontexty interkultúrnej komunikácie (Nitra 2009), a także autorem monografii: Metaforické modely obraznosti v poézii Jána Ondruša (Nitra 2008), Slovensko- macedónske literárne a kultúrne vztahy (Bratislava 2009) і Словакистички книжевни согледби - студии и интерпретации (Skopje 2011).

Kontakt: zvonko.taneski@gmail.com 